\title{
INDIKATOR PEMBELAJARAN AKTIF DALAM KONTEKS PENGIMPLEMENTASIAN PENDEKATAN PEMBELAJARAN AKTIF, KREATIF, EFEKTIF, DAN MENYENANGKAN (PAKEM)
}

\author{
Zulfahmi HB \\ Dosen Fakultas Tarbiyah dan Keguruan IAIN Imam Bonjol Padang \\ e-mail: hfahmihb@yahoo.co.id
}

\begin{abstract}
Although fun, active, enjoyable and creative learning as stated by Ministry of Education Affairs (2005) has been implemented on the basis of Education Unit Level Curriculum, there is no clear indicator for the implementation for such an approach. This article discusses fourteen indicators of active learning based on emergent theories. By understanding the indicator, it is hoped that the teacher are to create conducive classroom athmogphere. Thus, the students actively involve in the learning process, especially to ask questions and convey their ideas.
\end{abstract}

Key words: active learning, PAKEM, indicator, implementation

\begin{abstract}
Abstrak: Pendekatan pembelajaran PAKEM ditetapkan oleh Mendiknas semenjak tahun 2005 sebagai pendekatan yang harus diterapkan dalam pembelajaran sesuai dengan pemberlakuan KTSP. Meskipun demikian, belum ada kejelasan tentang indikator-indikator pembelajaran yang mengimplementasikan PAKEM. Artikel ini membahas tentang indikator pembelajaran aktif. Berdasarkan pelacakan teori tentang pembelajaran aktif, dirumuskan adanya empat belas indikator pembelajaran aktif. Dengan menerapkan keempat belas indicator tersebut, guru mampu untuk menciptakan suasana pembelajaran yang menyenangkan, sehingga siswa aktif untuk bertanya dan menyampaikan gagasan.
\end{abstract}

Kata Kunci: pembelajaran aktif, PAKEM, indikator, pengimplementasian

\section{PENDAHULUAN}

Pada tahun 2005, pemerintah melalui Mendiknas, mencanangkan pemberlakuan pengimplementasian penyusunan kurikulum yang dikenal dengan Kurikulum Tingkat Satuan Pendidikan atau disingkat KTSP, setiap satuan pendidikan (sekolah) diharuskan menyusun kurikulum secara mandiri dan otonom sesuai dengan standar-standar kependidikan yang ditetapan oleh Badan Standar Nasional Pendidikan (BSNP). Praktis, mulai tahun 2007 pemberlakuan tentang pengimplementasian KTSP sudah dilaksanakan di setiap satuan pendidikan.

Sejalan dengan itu, melalui PP No. 19 Tahun 2005 Bab IV Pasal 19 ayat 1 pemerintah menyatakan, "Proses pembelajaran pada satuan pendidikan diselenggarakan secara interaktif, inspiratif, menyenangkan, menantang, memotivasi peserta didik untuk berpartisipasi aktif serta memberikan ruang yang cukup bagi prakarsa, kreativitas, dan kemandirian sesuai dengan bakat, minat, dan perkembangan fisik serta psikologis peserta didik." Hal tersebut meru-pakan dasar yuridis formal tentang ketentuan guru perlu menyelenggarakan pembelajaran yang aktif, kreatif, efektif, dan menyenangkan (PAKEM).

Menurut Depdiknas (2009: 1) PAKEM merupakan singkatan dari Pembelajaran Aktif, Kreatif, Efektif, dan Menyenangkan. Pakar lain, misalnya Rusman (2010: 321) menyatakan bahwa PAKEM merupakan akronim dari partisipatif, aktif, kreatif, efektif, dan menyenangkan. Beberapa Lembaga Pendidikan Tenaga Kependidikan (LPTK) pun mengembangkan konsep PAKEM menjadi PAIKEM (misalnya UNP) dan ada juga yang mengembangkan menjadi PAKEMI. Huruf $I$ dapat dimaknai Inovatif namun ada juga yang memaknai menjadi Interaktif. Meskipun demikian, konsep dasarnya, sesuai dengan PP No. 19 Tahun 2005 adalah PAKEM. 
Realitas di lapangan menunjukkan bahwa pemahaman guru-guru terhadap konsep PAKEM cenderung bersifat personal. Artinya, guru-guru cenderung memahami bahwa PAKEM itu merupakan akronim dari Pembelajaran Aktif, Kreatif, Efektif, dan Menyenangkan tetapi tidak memahami esensi utama PAKEM, baik esensi per kata seperti apa itu pembelajaran aktif, pembelajaran kreatif, pembelajaran efektif, dan pembelajaran menyenangkan maupun esensi totalitas PAKEM. Jika pemahaman tentang PAKEM tidak normatif atau standar, tentu pengimplementasiannya juga akan bersifat relatif.

Berdasarkan kesenjangan antara konsep ideal dengan realitas tersebut, dalam artikel ini dibahas esensi pembelajaran aktif. Hal-hal lain, seperti esensi pembelajaran kreatif, efektif, dan menyenangkan tidak dibahas mengingat keterbatasan ruang.

\section{PEMBAHASAN}

\section{Kajian Teoretis Standar (Standard)}

Teori standar pertama tentang pembelajaran aktif dalam konteks PAKEM adalah teori yang diungkapkan oleh Depdiknas (2005, 2006, dan 2009). Menurut Depdiknas (2005: 3) kata aktif dimaksudkan bahwa dalam proses pembelajaran guru harus menciptakan suasana sedemikian rupa sehingga siswa aktif bertanya, mempertanyakan, dan mengemukakan gagasan. Selanjutnya, ditambahkan bahwa belajar memang merupakan suatu proses aktif dari si pembelajar dalam membangun pengetahuannya, bukan proses pasif yang hanya menerima kucuran ceramah guru tentang pengetahuan.

Pada uraian yang lain, Depdiknas (2006: 2) mengungkapkan konsep PAKEM di TK dan SD. Depdiknas mengungkapkan rincian tentang pembelajaran aktif, kreatif, dan menye-nangkan. Secara umum, Depdiknas (2006: 5) hanya mengungkapkan ciri umum pembelajaran di TK dan SD berbasis PAKEM, yaitu: (1) multimetode, multimedia, (2) praktik dan bekerja dalam tim, (3) memanfaatkan lingkungan sekitar, (4) berlangsung di dalam dan di luar kelas, serta (5) multiaspek yang mencakup logika, praktika, dan etika.
Berdasarkan kajian teori standar tentang PAKEM, disimpulkan bahwa indikator pembelajaran aktif dalam konteks PAKEM belum jelas. Untuk, itu, perlu kajian teori yang lebih mendalam tentang konsep hingga perumusan indikator pembelajaran aktif.

\section{Kajian Teoretis Terkembang (Elaborated)}

Pemikiran tentang pembelajaran aktif (active learning) bukan merupakan pemikiran yang bersifat regional, tetapi internasional. Para pakar bidang pendidikan di seluruh dunia secara antusias membahas konsep belajar aktif secara berkelanjutan. Bahkan, di Amerika Serikat (AS), tepatnya di Cedar City, Utah, didirikan Active Learning Foundation, sebuah yayasan nirlaba yang memberikan layanan konsultasi tentang permasalahan belajar dan pembelajaran aktif bagi individu, keluarga, kelompok masya-rakat, maupun tenaga kependidikan.

Pada umumnya, pakar pendidikan yang membahas pembelajaran aktif sependapat bahwa konsep pembelajaran aktif dapat dilacak dari pemikiran John Dewey. Tokoh ini merupakan salah seorang penganjur filsafat progresif yang juga beraliran pragmatis. Menurut Russel (2004: 1066) John Dewey (1859-1952), dikenal sebagai seorang filsuf terkemuka Amerika yang beraliran naturalistik. Dewey diberi predikat naturalistik sebab pandangan-pandangan dan penjelasan kefilsafatannya dilandasi oleh fenomena natural terhadap obyek-obyek dan peristiwa-peristiwa yang diterima oleh indera manusia secara pragmatis. Dengan demikian, Dewey juga dikenal sebagai pelopor filsafat pragmatisme.

Dewey sangat mengagungkan proses berpikir ilmiah yang bercorak induktif melalui inkuiri serta meyakini pentingnya peran pengalaman dalam berpikir. Pengalaman bukan sekedar akumulasi masa lalu, tetapi merupakan akomodasi guna memahami pengalaman baru dan merumuskannya sebagai akomodasi bagi pengalaman berikutnya. Proses ini berlangsung terus secara berkelanjutan. Dengan kata lain, dalam konteks pendidikan, Dewey meyakini bahwa pendidikan merupakan proses berkelanjutan yang mengakomodir pengalaman manusia untuk mampu memaknai dan merumuskan serta 
menginternalisasikan pengalaman-pengalaman baru kemudian didayagunakan lagi sebagai akomodasi bagi pengalaman mendatang. Pendidikan dipandang sebagai usaha untuk memajukan individu melalui proses inkuiri berkelanjutan sehingga mampu merancang, mengembangkan, dan menata kehidupan masa mendatang yang lebih baik dibandingkan dengan masa lampau.

Dalam buku How We Think Dewey menolak Teori Stimulus Respons ( $S$ - $R$ Theory) aliran behavioral karena menurut Dewey, children do not just imitate. Anak-anak merupakan subyek yang aktif. Urgensi aktivitas anak dalam belajar juga diungkapkan dalam buku The School and Society, bahwa dalam belajar, anak secara aktif mengkonstruksi, menemukan melalui inkuiri, mengungkapkan secara artistik, dan mengkomunikasikan hasil belajarnya. Konsep tersebut dikenal dengan learning by doing atau pembelajaran melalui berbuat, dan learning by experiencing atau pembelajaran melalui mengalami.

Dewey meyakini bahwa belajar itu adalah proses aktif mengaitkan pengalaman yang telah dimilikinya dengan pengalaman baru yang ditemukannya. Hasil pengaitan tersebut pada tahap selanjutnya digunakan sebagai fasilitas, alat, untuk melakukan inkuiri tentang sesuatu yang baru. Jadi, hal itu merupakan proses yang berkelanjutan.

Selain meyakini perlunya keaktifan dan pengalaman siswa, Dewey juga dikenal sebagai pelopor pembelajaran yang berpusat pada anak (child centered) atau berpusat pada siswa (student centered). Dalam pandangan Dewey, proses belajar adalah proses individual meskipun dapat berlangsung dalam konteks sosial. Siswa, secara individual, akan mengembangkan pengalaman yang telah dimiliki untuk memaknai pengalaman baru dan merumuskan pengalaman baru tersebut. Oleh sebab itu, siswa atau anak hendaknya dijadikan sebagai subyek pembelajaran, bukan obyek.

Menurut Robson (2010:1), pembelajaran aktif memberikan peluang seluas-luasnya untuk mengembangkan interaksi antara guru dengan siswa, antar siswa itu sendiri, serta antara siswa dengan bahan atau topik dalam suatu disiplin akademis. Keuntungan utama pengimplementasian pembelajaran aktif adalah: (1) memungkinkan tingginya tingkat partisipasi aktif peserta didik, (2) mendorong penggunaan pengalaman dan pengetahuan sebelumnya, (3) memungkinkan adanya perspektif/pandangan baru tentang topik atau materi, (4) memungkinkan berkembangnya konstelasi nilai dan asumsi dari berbagai disiplin ilmu, (5) memungkinkan berkembangnya sikap terbuka terhadap hasil pembelajaran, (6) memungkinkan adanya dukungan dan rekan rekan belajar, (7) mendorong adanya kristalisasi dan refleksi pengalaman, serta (8) mendorong adanya rasa tanggung jawab untuk belajar sehingga mengembangkan siswa untuk menjadi lebih mandiri dan mampu memotivasi diri.

Strategi pembelajaran aktif juga dikembangkan di Jerman pada tahun 1980-an sebagai perpaduan behaviorisme dan kognitivisme. Salah seorang penganjur strategi ini adalah Dave Meier dalam bukunya The Accelerated Learning Handbook (Sidjabat, 2010: 3). Menurut tokoh ini, konsep guru mengenai siapa manusia yang diajarinya (siswa) sangat menentukan pola-pola kegiatan belajar yang direncanakan dan dikelolanya. Meier mengkritik kecenderungan pendidikan di barat yang memandang manusia hanya sebagai konstruksi tubuh dan pikiran. Aktivitas tubuh dan pikiran dipisahkan dalam kegiatan belajar. Akibatnya, pembelajaran sangat kaku.

Menurut Meier, manusia memiliki empat dimensi yakni: tubuh atau somatis (S), pendengaran atau auditori (A), penglihatan atau visual (V), dan pemikiran atau intelek (I). Bertolak dari pandangan ini, Meier mengajukan model pembelajaran aktif yang disingkat SAVIsomatis, auditori, visual dan intelektual. Prinsip-prinsip yang melandasi SAVI adalah: (1) belajar melibatkan seluruh tubuh dan pikiran, (2) belajar adalah berkreasi, bukan mengkonsumsi, (3) kerja sama akan sangat membantu proses belajar, (4) pembelajaran berlangsung pada banyak tingkatan kognisi secara simultan, (5) belajar berasal dari mengerjakan pekerjaan itu sendiri, (6) emosi positif sangat membantu 
pembelajaran, serta (7) otak-citra menyerap informasi secara langsung dan otomatis.

Menurut Bonwell and James A. Eison (2010: 1) aspek kesadaran siswa dalam melakukan sesuatu dalam pembelajaran merupakan kunci pembelajaran aktif. "Within this context, it is proposed that strategies promoting active learning be defined as instructional activities involving students in doing things and thinking about what they are doing" (Melalui konteks ini, dianjurkan bahwa strategi untuk memicu pembelajaran aktif dapat didefinisikan sebagai aktivitas pembelajaran yang melibatkan siswasiswa dalam melakukan berbagai hal dan memikirkan apa yang mereka lakukan tersebut).

Fink (2010: 1-2) mengungkapkan bahwa pembelajaran aktif dapat disederhanakan sebagai pembelajaran yang memaksimalkan siswa memiliki pengalamandan dialog. Gambaran singkat tentang aktivitas utama siswa utama pembelajaran aktif adalah sebagai berikut ini.
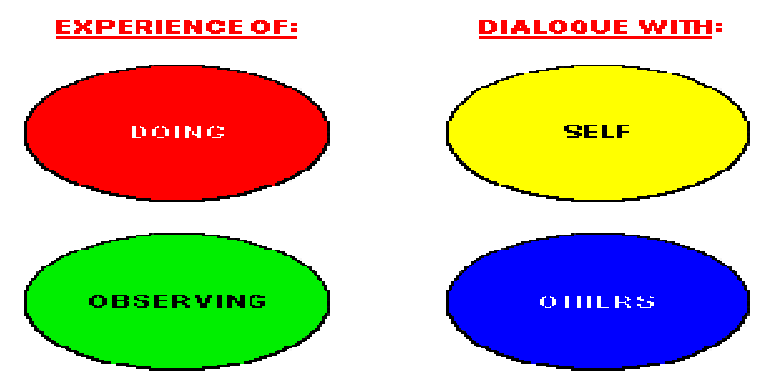

\section{Gambar 1 Aktivitas Utama Siswa dalam Pembelajaran (Fink, 2010)}

Dialog dengan diri sendiri adalah proses yang memungkinkan siswa mulai berpikir secara reflektif mengenai topik yang dipelajari. Mereka menanyakan pada diri mereka sendiri mengenai apa yang mereka pikir atau yang harus mereka pikirkan serta apa yang mereka rasakan mengenai topik yang dipelajari. Pada tahap ini, misalnya dalam pembelajaran bahasa Indonesia dengan topik menyimak khotbah, guru dapat meminta siswa untuk menyimak khutbah. Sudah itu, guru menugasi siswa menuliskan kembali ide utama yang diungkapkan dalam khutbah, bagaimana proses mereka menyimak khutbah, dan apa pengaruh isi khutbah tersebut terhadap diri mereka.
Dialog dengan orang lain bukan dimaksudkan sebagai dialog parsial sebagaimana yang terjadi pada pengajaran tradisional, tetapi dialog yang lebih aktif dan dinamis ketika guru membuat diskusi kelompok kecil tentang topik yang telah dipelajari. Lazimnya, dialog dengan orang lain ini dikembangkan melalui kerja kelompok atau kegiatan berpasangan.

Observasi terjadi ketika siswa memperhatikan atau mendengar seseorang yang sedang melakukan sesuatu hal yang berhubungan dengan apa yang mereka pelajari, apakah itu guru atau teman mereka sendiri. Untuk memaksimalkan hasil observasi, guru dapat memberikan panduan atau pedoman observasi. Selain itu, kegiatan observasi juga dapat dilakukan secara berkelompok atau berpasangan.

\section{Indikator-indikator Pembelajaran Aktif}

Berdasarkan deskripsi teori tentang pembelajaran aktif, disimpulkan empat belas hal tentang pembelajaran aktif. Keempat belas hal tersebut adalah sebagai berikut ini.

Pertama, pembelajaran hendaknya berpusat pada siswa (student centred). Oleh sebab itu, materi pembelajaran hendaknya dikaitkan dengan kebutuhan, minat, dan orientasi siswa dalam kehidupan nyata. Jika materi pembelajaran hanya perlu dalam pandangan guru, siswa tidak akan berpartisipasi aktif dalam proses dan pemerolehan hasil belajarnya.

Kedua, pembelajaran hendaknya didasarkan atas tujuan yang jelas dan dipahami siswa. Guru hendaknya mengkomunikasikan tujuan pembelajaran sebelum proses pembelajaran dilaksanakan. Tanpa kejelasan tujuan, siswa tidak mungkin terlibat aktif dalam proses dan pemerolehan hasil belajarnya.

Ketiga, pembelajaran aktif hanya dimungkinkan jika siswa dihadapkan pada suatu masalah yang perlu dipecahkan sehingga siswa melakukan proses penemuan. Namun, perlu dipertimbangkan kualitas masalah tersebut. Jika masalah terlalu ringan atau mudah untuk dipecahkan siswa cenderung tidak termotivasi. Sebaliknya, jika masalah terlalu berat atau sukar 
(mungkin disebabkan juga oleh ketidakmampuan guru mengemas masalah tersebut) siswa cederung menarik diri atau tidak termotivasi.

Keempat, untuk melakukan penemuan, siswa hendaknya memiliki rambu-rambu yang jelas. Rambu-rambu tersebut dirumuskan bersama oleh guru dan siswa, atau dirumuskan guru namun disetujui, dikomunikasikan, dan dipahami siswa.

Kelima, pembelajaran aktif adalah pembelajaran yang memungkinkan siswa mengaitkan pengalaman atau pengetahuan siap yang telah dimilikinya dengan pengalaman baru yang ditawarkan guru dalam bentuk masalah tersebut. Selanjutnya, interrelasi pengalaman tersebut akan mengembangkan kesadaran siswa tentang kebermaknaan pembelajaran bagi kehidupan, baik kehidupan sehari-hari maupun kehidupan akademis. Jika tidak terdapat pengaitan dan interrelasi pengalaman, pembelajaran tersebut tidak akan bermakna bagi siswa.

Keenam, pembelajaran aktif adalah pembelajaran yang memungkinkan adanya perspektif/pandangan baru siswa tentang topik atau materi pembelajaran. Perspektif baru tentang topik atau materi hendaknya bukan karena dijejalkan guru, tetapi sesuai dengan pengalaman ketika melakukan proses penemuan dan pemecahan masalah. Oleh sebab itu, keaktivan siswa dapat diunjukkan melalui menanyakan, menanggapi, menyanggah, atau mengusulkan sesuatu kepada kelas (siswa lain dan guru).

Ketujuh, pembelajaran aktif hendaknya memungkinkan berkembangnya konteslasi nilai dan asumsi dari berbagai disiplin ilmu dalam diri siswa. Pembelajaran tentang menyimak berita, misalnya, hendaknya mampu mengembangkan kesadaran siswa bahwa berita yang baik bukan hanya didasarkan atas penggunaan bahasa yang baik dan benar, tetapi juga didasarkan atas wawasan keilmuan (sosiologi, psikologi, antropologi, dan sebagainya) penulis berita.

Kedelapan, pembelajaran aktif hendaknya memungkinkan siswa mengembangkan sikap terbuka terhadap hasil pembelajarannya. Artinya, siswa memahami hasil-hasil pembelajaran yang telah dicapai sesuai dengan topik dan menyadari hal-hal apa yang belum dipahami.

Kesembilan, untuk menfasilitasi memahami permasalahan dan mengaitkan pengalaman siap dengan pengalaman yang baru, pembelajaran aktif memerlukan media yang layak. Konsep kelayakan media jelas bersifat relatif tergantung pada karakteristik siswa, materi, tujuan pembelajaran, sarana dan prasarana, serta kemampuan guru. Namun, dalam pembelajaran menyimak, karakteristik utama media yang diperlukan siswa adalah media yang memungkinkan siswa mengembangkan kemampuan auditori. Jadi, media tersebut dapat berupa media audiovisual atau yang paling sederhana adalah media auditif. Untuk pembelajaran menulis, misalnya menulis artikel, media teks tertulis merupakan hal yang mutlak diperlukan agar siswa tidak mengembangkan verbalisme tentang artikel dan langsung memperoleh gambaran yang jelas tentang artikel tersebut beserta karakteristiknya.

Kesepuluh, pembelajaran hanya dimungkinkan jika siswa memiliki kesadaran bahwa dirinya merupakan subyek yang bertanggung jawab secara mandiri, baik dalam proses maupun pemerolehan hasil belajarnya. Faktor kesadaran dan tanggung jawab individual siswa merupakan faktor yang penting karena siswa akan aktif memilih, merencanakan, melaksanakan, dan mempertanggungjawabkan strategi individual guna mencapai keberhasilan belajarnya. Untuk itu, siswa hendaknya mengembangkan kesadaran tentang apa tujuan pembelajaran yang hendak ditempuh, apa manfaatnya baik dalam kehidupan sehari-hari maupun dalam konteks akademis, sosial, dan pengembangan diri, apa langkah yang harus ditempuh dalam pembelajaran, bagaimana melaksanakan langkah-langkah tersebut, dan berani menanggung resiko atas hal-hal yang sudah disadari dan dilakukannya dalam proses pembelajaran.

Kesebelas, pembelajaran tidak hanya melibatkan aktivitas fisik dan mental tetapi juga keseluruhan indera. Seluruh faktor tersebut akan 
digerakkan jika siswa menempuh prinsip belajar sambil berbuat dan belajar melalui mengalami. Dengan kata lain, aktivitas tersebut akan mengembangkan kesadaran siswa tentang pembelajaran yang bermakna atau meaningful learning.

Keduabelas, dari sudut aktivitas otak, pembelajaran bukan hanya melibatkan aktivitas belahan otak sebelah kanan namun juga kiri. Dengan kata lain, faktor kesadaran dan ambang sadar hendaknya dikembangkan secara maksimal. Faktor emosi sangat tergantung pada penciptaan suasana yang menyenangkan dalam konteks kelas yang demokratis. Siswa hendaknya juga mampu mengendalikan emosi dan dapat menikmati proses dan pemerolehan hasil belajarnya.

Ketigabelas, meskipun pembelajaran merupakan aktivitas individual, namun faktor interaksi sosial juga sangat menentukan. Interaksi sosial, baik antara siswa-guru, siswasiswa lainnya, siswa lingkungan merupakan manifestasi kemandirian dan tanggung jawab individu dalam konteks kebersamaan melalui kerja sama. Kebersamaan dan kerja sama sangat diperlukan dalam pembelajaran bahwa karena fungsi utama ba-hasa adalah alat komunikasi sehingga belajar bahasa berarti belajar berkomunikasi. Komunikasi tidak mungkin terjadi jika tidak ada konteks, di antaranya adalah pengirim dan penerima pesan atau peserta komunikasi.

Keempatbelas, pembelajaran aktif dipengaruhi oleh umpan balik. Bagi siswa, umpan balik dimanfaatkan untuk merefleksi apa yang telah dipelajari, apa yang belum dikuasai, apa yang dapat direncanakan dan dikerjakan pada masa mendatang untuk mengembangkan hal-hal yang telah dipelajari, dan apa manfaat materi tersebut bagi pengembangan keilmuan maupun kehidupan masa mendatang. Bagi guru, umpan balik dapat dimanfaatkan untuk mencermati kelemahaman dan kekuatan pembelajaran yang telah dilaksanakan dan mengembangkan pembelajaran yang lebih baik pada masa mendatang.
Secara umum, untuk menerapkan keempat belas indikator pembelajaran aktif, digunakan model atau alur sebagai berikut.

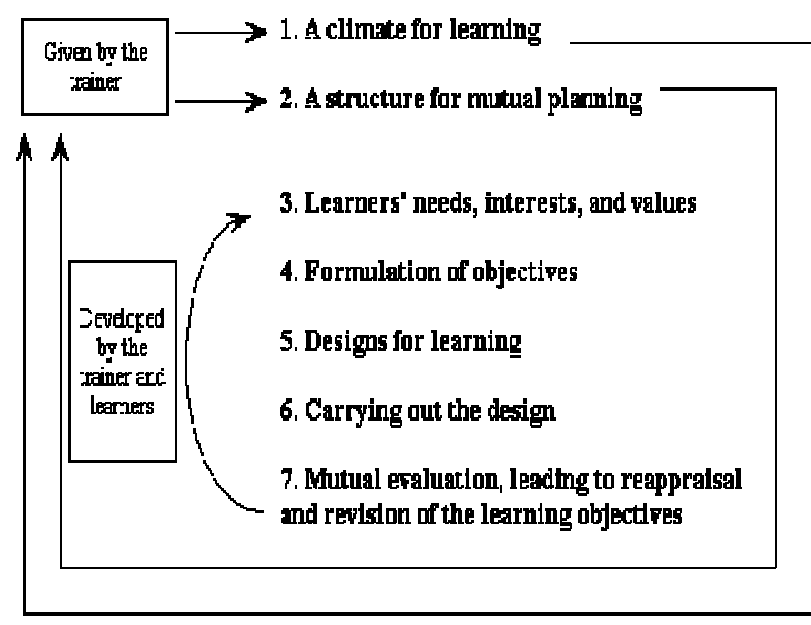

Gambar 2 Model Umum Penerapan Pembelajaran Aktif (Laird, 2012)

Berdasarkan bagan di atas, diperoleh gambaran bahwa pembelajaran aktif itu merupakan hasil rancangan bersama antara pengajar (trainer) dengan siswa (learner). Langkah awal, pengajar menciptakan iklim yang memungkinkan terjadinya proses pembelajaran secara maksimal. Langkah berikutnya, pengajar bersama-sama siswa menyepakati perencanaan pembelajaran yang akan dilaksanakan.

Perencanaan bersama ini memungkinkan terciptanya kontrak pembelajaran yang mengikat pengajar-siswa dalam melaksanakan pembelajaran. Efek lainnya, pelaksanaan evaluasi pembelajaran pun didasarkan atas kesepakatan pengajar-siswa tersebut.

\section{SIMPULAN}

Pembelajaran aktif didasarkan atas konsep belajar berdasarkan pengalaman (learning by experiencing) dan belajar sambil berbuat (learning by doing). Keaktifan siswa bukan hanya diwujudkan dalam bentuk aktivitas fisik tetapi juga mental atau kognitif. Keaktifan siswa tersebut dapat dilihat dari empat belas indikator yang memiliki hubungan erat antara yang satu dengan yang lain yaitu: (1) berpusat pada siswa, (2) didasarkan atas tujuan yang jelas, (3) bersifat pemecahan masalah, 
mengoptimalkan kegiatan penemuan atau inkuiri, (5) memungkinkan siswa mengaitkan pengalaman yang telah dimiliki dengan pengalaman baru, (6) memungkinkan adanya perpektif baru pada diri siswa tentang apa yang dipelajari, (7) memungkinkan berkembangnya konteslasi nilai dan asumsi dari berbagai disiplin ilmu dalam diri siswa, (8) memungkinkan siswa mengembangkan sikap terbuka terhadap hasil pembelajarannya, (9) didasarkan atas penggunaan media pembelajaran yang layak, (10) hanya dimungkinkan jika siswa memiliki kesadaran bahwa dirinya merupakan subyek yang bertanggung jawab secara mandiri (11) melibatkan aktivitas fisik, mental, dan keseluruhan indera, (12) pembelajaran bukan hanya melibatkan aktivitas belahan otak sebelah kanan namun juga kiri, (13) terjadi dalam interaksi sosial yang kondusif dan dinamis, serta (14) ada umpan-balik.

\section{DAFTAR RUJUKAN}

Bonwell, Charles C. \& James A. Eison 2010. "Active learning: creating excitement in the classroom". http://www. ntlf.com/. (Diunduh 22 juni 2010).

Depdiknas. 2005. Pengembangan Model Pembelajaran yang Efektif. Jakarta: Direktorat Jenderal Manajemen Pendidikan Dasar dan Menengah Departemen Pendidikan Nasional.

Depdiknas, 2006. PembelajaranAktif, Kreatif, Efektif, \& Menyenangkan (PAKEM): di TK dan SD. Jakarta: Dirjen PDM.
Depdiknas. 2009. "PAKEM (1)". http://eduarticles.com/ (Diunduh 8 Juli 2010).

Fink, L. Dee. 2010. “Active Learning”. http://honolulu.hawaii.edu/intranet/ committees/FacDevCom/index.htm.(D iunduh 2 Juni 2010).

Laird, John E. 2012. Learning Process. (dalam "Active Learning", www. nwlink. com/.../hrd/learning/active.htm, diunduh 4 Desember 2011).

Rusman. 2010. Model-model Pembelajaran: Mengembangkan Profesionalisme Guru. Jakarta: Rajawali Pers.

Russel, Bertrand. 2004. Sejarah Filsafat Barat: Kaitannya dengan Kondisi SosioPolitik Zaman Kuno hingga Sekarang. (Diterjemahka oleh Sigit Jatmiko, dkk). Yogyakarta: Pustaka Pelajar Offset.

Sidjabat, B.S. 2010 "Teori Belajar Aktif dalam Pembelajaran PAK". http://www. tiranus.net/teori-belajar-aktif-dalampembelajaran-pak/ (Diunduh 20 Juni 2010).

Robson, Jocelyn. 2010. "Active Teaching and Learning". Strategi pembelajaran active learning/ (Diunduh 11 Desember 2010). 